\title{
REFLECTIONS ON ARAUCANIAN/MAPUCHE RESILIENCE, INDEPENDENCE, AND ETHNOMORPHOSIS IN COLONIAL (AND PRESENT-DAY) CHILE
}

\author{
Tom D. Dillehay
}

This essay addresses an anthropological and historical understanding of the concepts and practices of an indigenous sovereignty, specifically the Araucanian polity, from the early Spanish contact period to briefly the present. The Araucanians or Mapuche, as they are known today, are located in the south-central Andean region of Chile. Although the primary focus is on the middle $16^{\text {th }}$ to middle $17^{\text {th }}$ centuries during the Arauco War ( AD 1551 to 1641), the Mapuche successfully resisted the Spanish conquest for more than 250 years by forming a confederated proto-state or polity comprised of partner domains (i.e., Catiray, Arauco, Tucapel, Puren) and different ethnic groups. The Spanish called this polity the "Estado Indomito" ("unconquered state"; see Ercilla y Zúñiga [1569] 1982). In 1641, the Spanish Crown recognized the polity as a sovereign political order. The Chilean historian Alberto Medina interprets the meaning of the term estado as it was used in the $16^{\text {th }}$ century.

The word "estado" in Ercilla [y Zuñiga] and the $16^{\text {th }}$ chronicles has a precise meaning related to the general idea that the term had at that time: the territory ruled by a prince, monarch or sovereign, by a chief with subjects, by a lord of vassals or serfs... (A. Medina 1978:144).

It is important that royal opinion in Spain during this period recognized another imperial sovereign, an indigenous one in the Americas, despite the fact that the Spaniards saw the "indios" as pagan, barbarian, and idolatrous. In fact, the Araucanians constitute the only indigenous ethnic group in the Americas that concluded a formal treaty and established political boundary with the Spanish Crown. Spanish conquistadores, clergy and soldiers and Araucanian leaders, shamans and warriors represented the same kind of entity: namely the sovereignty of a pre-modern state or polity. In the midst of culture contact, the Araucanians and the Spanish disagreed about the nature of what was happening with respect to their individual roles in the prolonged conflict between them. The Araucanians saw the Spaniards as outsiders and invaders; the Spaniards saw the Araucanians as an expendable labor force to extract gold and other resources for the Crown and as another indio group in need of religious conversion and political control (e.g., Bengoa 1999, 2003; Zavala 2008). Such encounters are interesting because they offer for consideration moments of what we might call ontological rupture. That is, simply the clash and consequence of different worldviews between two societies in culture contact.

The $16^{\text {th }}$ century Spanish kingdoms (empire) constituted one of the first modern states in the world. The empire fits within the definition of an early Western sovereignty (see discussion below). During this period, Spain had become accustomed to the acquisition of overseas lands by conquest and to disregarding the will of the conquered original inhabitants of the land. They treated the conquered as legally irrelevant-as Aristotelian "natural slaves" and as "savages" to be converted by joint action of the military and the church (U.N. Doc. E/CN.4/ Sub.2/1993/29 1996).

The Araucanian polity does not necessarily meet the definition of an early modern sovereignty. They represented an evolving southern Andean polity, one that occasionally engaged in warfare with neighboring ethnic groups. This polity developed more formally during the Arauco War to meet the new demands and needs of an ethnic society undergoing intense pressure from Spanish agents. The Araucanians were (and the Mapuche still are) a patrilineal, patrilocal, and bilateral society that recognized its kin on both the mother and father's sides. In the past, the Araucanians resided in dispersed communities. In the anthropological literature, they are best known as having had a mixed economy of piñon collectors in the Andes and fisherfolk, hunters, gatherers, and agriculturalists in the central valley and along the Pacific coast (Dillehay 2007, 2014). Prior to the arrival of the Spanish, their past political organization was characterized by small to large cacicazgos or chiefdoms, except in times of war against the Spanish and later the Chileans when more formal, semi-centralized polities headed by guen-toqui war leaders were formed to defend their lands. It was not until the end of the $19^{\text {th }}$ century that 
the Mapuche were finally defeated by the Chilean army and confined to reducciones.

For the $16^{\text {th }}$ to $17^{\text {th }}$ century Araucanians, the transition from initial contact to widespread organized resistance was marked by local centralization of political power at the lof (local patrilineal community) and regua (multi-patrilineal communities) levels but regional non-centralization at the ayllaregua (multi-regua at the regional scale) and butanmapu (multi-ayllaregua at the interregional scale) levels (Zavala 2011). I say non-centralization because centralized political power among the Araucanians at the broader territorial level and at a specific polity-capital or -center of government never existed, although they had an effective system of self-governance at all levels and designated regions of primary military operation. Political power, authority and leadership within the warring Araucanian society were derived primarily from resistance and resilience and were linked to an assertion of absolute defense of the homeland, with the legitimacy of rule based on patriarchy, ancestor worship, religion and largescale public ceremony. In order to understand this polity as an indigenous "sovereign state" during the $16^{\text {th }}$ and $17^{\text {th }}$ centuries and to grasp the meaning of the Mapuche's current demands for political autonomy and self-determination in Chile today (c.f., Comisión de Comunicaciones 2013; Figueroa 2015; Millaleo 2011; Marriman 2013), we need to consider a broader definition of sovereignty.

After a brief review of the concept of sovereignty, I consider the indigenous political structure, sovereignty, and self-determination of the Araucanian Estado. In an attempt to broaden our consideration of sovereignty, I examine the concept from the perspective of social and cultural variables that extend beyond modern notions of an independent authority over a geographic area (e.g., territory or nation state) and of the ability of the modern nationstate to guarantee the best interests of its own citizens (Bateman 2011; Herr 2014). Identifying these issues is fairly straightforward in the early Spanish written records. Although sparse, these records provide sufficient detail on the inter-societal relationships between the Spanish and the Araucanians and on their respective attitudes and approaches to contact (e.g., Ercilla y Zúñiga 1982 [1569]; Góngora Marmolejo 1990 [1575]; González de Nájera 1889 [1614]; Marino de Lobera 1960 [1580]; Olaverría 1852 [1594]; Rosales 1989 [1674]; L. de Valdivia
1887 [1606]). Lastly, I briefly discuss the political and ethnic struggles of the Mapuche in Chile today.

The last Chilean census placed the number of Mapuche at approximately eight hundred thousand to one million (INE 2010), with approximately half living on scattered reducciones (c.f., Crow 2013; Faron 1962;). About thirty thousand more live in the Andean mountains to the east in Argentina, making them the largest indigenous group in the southern cone of South America. Although the rural Mapuche today are different from their colonial period ancestors, many are still agriculturalists and pastoralists and they still perform traditional public ceremonies where political and social issues are resolved.

\section{Relevance of Indigenous Sovereignty}

At stake in this type of discussion is how we reconstruct pre-modern and indigenous figures like the Araucanian sovereignty and their right of self-determination, how these sovereignties were governed, and what sorts of sovereignties are implied when those accounts intersect with today's global debates. Sixteenth-century European colonialism created a world in which the kinds of beings (e.g., pagans, barbarians, and idolaters) perceived in ethnic groups like the Araucanians are obviously no longer sustainable in today's modern setting. Nonetheless, many indigenous and impoverished peoples in the world are still seen as backward, undeveloped, and unworthy or incapable of self-rule and selfdetermination; they often are viewed as an obstacle and nuisance to global development. In many ways, our present world and attitude towards indigenous people are still an extension and continuation of the $16^{\text {th }}$ century ones.

In the modern study of indigenous peoples, a major issue concerns ethnic origins and initial cultural development. Interest in explaining the original territory and self-determination of these peoples partially relates to differentiating them through distinct historical and cultural processes and to a close examination of their contemporary ethnic and legal status within modern nation-states (Dean and Levi 2003; Hunefeldt and Sussex 2011). Today, all indigenous peoples live in socially complex, multi-layered nation states. They often have the burden of having their cultural perspectives romanticized or denigrated and their ethnic status usually is disempowered, making it impossible for 
them to protest the exploitation of their cultural images and resources. At the same time, through today's globalized media and institutions, many groups are finding new sources of empowerment, one of which is reconsideration of their rights as sovereign "pueblos originarios" (the first people of the land; see Boccara and Bolados 2008; Haughney 2006; U.N. Doc. E/CN.4/Sub.2/1993/29 1993). Despite these sources, most indigenous people still struggle with social justice, full recognition of their ethnic identity, racism, agency, and rights, and with the politics of resource and territorial control (see Brysk 2000). The Mapuche case is no different; they struggle within Chile and Argentina from racial discrimination and for ethnic recognition, self-rule, and access to and control of their own resources. These issues are significant in the rapidly changing and globalizing world of today. Furthermore, on a global scale, the political presence of indigenous peoples has increased significantly during the past twenty years. They now have become important actors in international and domestic law and policy and in negotiating access to the wealth of natural resources on their lands (Herr 2014).

\section{Sovereignty, Self-Rule, and Governance without Government}

When one reviews the Western concept of sovereignty, it becomes apparent that it has many dimensions in past and present nation states. Much of the recent literature is critical of the idea of "sovereignty" as it has generally been known. For instance, one scholar has described the concept as "organized hypocrisy" (Krasner 1999). Others have referred to it as being "of more value for purposes of oratory and persuasion than of science and law" (Fowler and Bunck 1995; cf. Barker 2005). Although often criticized, the concept of "sovereignty" is still central to most present-day thinking about international relations and international law. The "Westphalian" concept (ca. 1648) of a nation state's "right" to exercise absolute power with regard to its territory (usually including conquered lands and peoples) has been negated in many ways, but it is still applied by those countries that hold certain "realist" views or that attempt to prevent foreign or international powers from intervening in their government's decisions and activities.

Sovereignty also has been conceived as a "social construct." According to this view, "Numerous practices participate in the social construction of a territorial state as sovereign, including the stabilization of state boundaries, the recognition of territorial states as sovereign, and the conferring of rights onto sovereign states..." (Weber and Biersteker 1996:298). Set in this context, sovereignty as a social construction encompasses various aspects of a society's culture, including its religious, economic, ontological, and political institutions. This is one consideration of sovereignty that is perhaps most characteristic of many pre-modern states and of indigenous groups whose lands are located within the boundaries of modern nation states.

The point is that most indigenous concepts of sovereignty do not necessarily follow Western ideas of power over people and territory ${ }^{1}$. Indigenous concepts generally believe in self-governance (which can be without a formal government structure) under the rubric of self-determination ${ }^{2}$, which is based on the "authentic aspirations" of indigenous peoples and their "inner worlds" or ontologies. Indigenous sovereignty is a largely social creation, beginning with a regime of respect when governing people (Barker 2005; McCue 2007). Indigenous formulations of self-rule attempt to build frameworks of respectful coexistence by acknowledging the integrity and autonomy of the various constituent peoples and/ or ethnic groups within a territory. They strive to go beyond the most liberal Western conceptions of sovereignty by allowing for social and cultural differences while mandating the construction of solid relationships among the constituent elements (see later discussion on Mapuche sovereignty in Chile today). In short, from an indigenous prospective, sovereignty is not just human-centered and hierarchical; it is not solely born or sustained through conquest and force. In today's world, it is formed through an effort to establish peace, respect, and balance; it also is sacred and renewed with ceremonies that are rooted in the land (sensu Taiaiake Alfred (2005); Deloria in Pavlik 2008; McCue (2007)). Many of these same elements, of course, also characterize the sovereignty of several modern nation-states. The difference is that decisionmaking and policy formation are filtered through these elements in many indigenous societies, which is not necessarily the case in the former.

To elaborate briefly on these latter issues, indigenous societies are usually tied together by kinship, exchange, and religious networks in a spider web-like strategy to organize the political 
architecture of an ethnic or multi-ethnic territory (e.g., Sahlins 1985; Taylor 2004). These societies are not always politically centralized and structured as polities with strict territorial boundaries and formal governing procedures. Rather their boundaries and political systems are often permeable and malleable, allowing for the formation of multi-ethnicity and cultural pluralism. This condition may be close to what Wallace (1996: 439-460) has termed "government without statehood," and what Prodi (2000) has called "self-governance" rather than a sovereign government. To Prodi (2000), governance "represents an inherently more leveling and pluralistic institutional arrangement, one ideally suited to an enlarged, multiethnic and demographically scattered polity." Governance transcends the idea of a formal "government" of a nation state: "it is a system in which power is located not in a bounded, singular, or a sovereign state, but in customs, rules, processes, and multi-level institutions." That is, governance entails pluralism, networking, agency, and dialogue between "social partners." In this system, decision-making involves input from a plurality of differentially positioned actors or partners. "Governance" draws together actors and institutions across multiple social, religious and political levels, in a way that empowers all community members. An example of governance in today's world might best be represented by the European Union (Shore 2006). In the past, several pre-industrial polities may fit this model, including the Araucanians, Hawaiians, the Chibcha of Colombia, the Lacandon Maya, among others.

\section{Araucanian Self-Determination without Statehood and Government}

Like most studies of the early colonial period the Araucanian case is a discourse on power relations: how the Spanish state (empire) affected indigenous community politics, how Araucanian leaders (i.e, guen-toqui, ulmen, hechiceros) organized their communities to resist the Spanish, how power relationships altered both societies, their political structures and their ontologies, and how conflict and demographic turmoil built increasingly higher levels of political organization within the Araucanian Estado. Although higher levels of political order were achieved throughout the course of the Arauco War, the order was a loose structure rather than a formally integrated one. It was comprised of a multi-level political system (i.e., lower lof to higher butanmapu levels) with diverse and independent yet partnered member provinces and segments of neighboring ethnic groups (e.g., Pircunche to the north, Pehuenche to the east, Huilliche to the south) within which several small politics revolved around the rules of local autonomy, agency, and identity.

In the Araucanian case, we cannot think in terms of traditional hierarchical layers of political organization and of a strict geographical boundary of the ethnic polity. Instead, we must think of a networking arrangement of political partners or sub-ethnic domains, with all levels of religious and political governance shaping, proposing, implementing and monitoring policy, military action, and self-rule together. As the North American historian Padden has expressed:

The existence of a skilled and effective military force bespeaks the presence of a comparable political organization under whose genius it is formed and directed. In the development of Araucanian political organization the chronicles indicate two major forces at work: the geographical particularism in which the Araucanians traditionally lived and a counterforce provoked by the presence of the enemy and inclining towards Araucanian unity. Throughout the first century of conquest, ancient localism clashed with incipient nationalism. This conflict produced a political ambivalence that in itself contributed heavily to the cause of Araucanian independence. Centralization of politico-military authority was achieved to a point where successful resistance was possible, but did not develop to a state where the Spaniards could defeat and usurp it (Padden 1993:85).

Changes in the countryside during the Arauco War era forced many Araucanians to eventually think and act beyond their own local kinship network and community affairs. The changing population and political conditions of the war exacerbated social cleavages and altered the demographic dynamics in many communities. These conditions spurred the rapid appearance of new agencies of change such as a stratum of war leaders (quen-toqui), a stratum of warriors (cona), larger and more frequent public ceremonies (i.e., coyantun, nguillatun, cahuin), now 
organized to bring about greater political solidarity, and widespread conscription in a new and growing ethnic consciousness, an "ethnogenesis" (formation of a new ethnic group), and identity within the society at large (Boccara 1999, 2002; c.f. Bengoa 2003; Goicovich 2003; Leiva 1977; Zavala 2000, 2008). The French social anthropologist, Guillaume Boccara, associates these developments with responsive transformations towards a new ethnicity and ethnic nationalism created by the warring Araucanians. $\mathrm{He}$ also recognizes the influence of a priori indigenous political structures in these transformations.

Like many of the populations encountered by the conquistadors at the frontiers of the great Inca and Mexica empires, and in Amazonia, the reche [the earliest term applied by the Spanish to the Indians living in the Araucania] were considered a people "without King, without faith, without law." The term used repeatedly to describe the organization of those groups located on the southern frontier of Tawantinsuyu was behetria [meaning a free settlement whose occupants had the right to elect their own leader]. The principal characteristic of the settlement pattern of these groups was dispersal; their sociopolitical organization was acephalous, that is, characterized by the absence of obedience to a political figure, a chief, who had the means to exercise his authority (Boccara 1999: 427).

One of the noteworthy changes in reche sociopolitical and territorial structure [as a result of contact with the Spanish] was precisely the institutionalization of the ayllarehue and the futamapu, which from temporary units in prehispanic times became permanent political associations in the colonial system with their own political representatives. ... Thus, the war of resistance brought with it the fundamental transformation of society, it was essentially a vector of acculturation and [ethnogeneis] (Boccara 1999:434; cf. Boccara 1998).

(I am not entirely convinced by this argument. There were many elements of the original Araucanian ethnicity that remained intact, including the economy, the religion structure, kinship organization and so forth. In this regard, I think it is best to speak of ethnomorphosis rather than ethnogenesis, that is, a change from one state of ethnicity to another. Most of these changes occurred politically, socially, and demographically in the region of the Estado and later in other regions. I partially disagree with Boccara's idea because an Araucanian ethnicity already existed at the time of the arrival of the Spanish; afterwards, it simply intensified and changed into a more formal and politically and materially visible entity (Dillehay 2014)).

Wartime mobilization also transformed political discourse and how local populations came to understand their specific roles in the wider struggle. The result was the mobilization - militarization - of labor and resources, initially in the Estado region, where the Spanish were most active, through the intensification of leaders who organized and recruited populations to the war effort. Due to incremental demographic and social changes, a complex web of political and social networks constructed and reconstructed social identities and shifting loyalties either with or mostly against the Spanish. Local populations did not always act as a cohesive political unit to front the Spanish. Some populations moved in and out of the war effort, serving as indios amigos (friendly or allied groups that constituted a small percentage of about $15 \%$ of the total indigenous population) siding with the Spanish one moment and fighting with the indios enemigos (enemy groups) and against them the next (see Zavala 2008).

This ambivalence also worked in favor of the Araucanian independence and self-rule; it also worked against political centralization because the polity never united from within. Instead, it was confederated, semi-centralized and comprised of multiple complementary partners, each with overlapping yet also distinct roles in service of the war effort. A consensual body of leaders (e.g., quentoqui) ruled the polity, with one often acting as the principal organizer. These leaders transformed local patrilineal communities into nonlocal communities mixed with kin, non-or fictive kin, and other groups demographically fragmented by warfare (Dillehay 2007, 2014; Dillehay and Zavala 2013; Goicovich 2006; Sauer 2012). It was a collective action, formed under the rubric of ethnic and often multi-ethnic customs and practices that led to the development of Araucanian sovereignty.

In sum, although the Araucanian polity was not completely a unified, sovereign body because it 
never attained a centralized political function and a formal territorial or state boundary, it had a clear and coherent project, i.e., to defend its independence, its ethnic integrity, and its governance system. This system was a "networking arrangement" of trans-territorial, supra-ethnic, and inter-institutional leaders. It was a system that employed numerous large-scale public ceremonies to maintain religious, political, and social cohesion across fragmented territories and shifting alliances. It constantly reminded people of the strict adherence of admapu (ancestral customs) and the Araucanian way of doing things, discouraging the adoption of European ideas, goods, and technologies. (The exception here is the immediate adoption of the horse and certain food crops such as wheat and barley.) Thus, what best defines this polity was not its unfettered independence or its legitimate use of violence to defend itself and its territory, as some traditional Western definitions might have it, but those everyday routines, rituals, activities, decisions, customs, and policies that regulated the social making of meaning and of patriotic ethnic subjects. This is a somewhat different approach to our current thinking concept of sovereignty.

In arguing these points, I do not wish to imply that all pre-modern indigenous polities can be reduced to a set of disembodied functions, customs, rituals, or discourses, or that the problem of analyzing a polity like the Araucanian can somehow be divorced from the question of its institutional and historical basis. On the contrary, these kinds of polities were (and are) very much embodied entities; ones whose presence was (and is) manifested in, and through, their socio-cultural institutions and their claim to sovereignty over a given ethnic territory. While warfare and defense were at the center of their lives, the core of this center was comprised of a commitment to the integrity and survivability of the culture and society.

\section{The Governance of Sovereignty and Redistributive Politics}

I have emphasized that the Araucanian population was undergoing significant transformations in the late $16^{\text {th }}$ and early $17^{\text {th }}$ centuries and that these transformations were well rehearsed in concerns over defense, security, ethnic nationalism, and preservation of their culture and lifestyle (c.f., Aylwin 1998; Bengoa 2003; Boccara 1999; Dillehay 2007;
Leiva 1977; Zavala 2008). As the Chilean historian Leiva has noted:

The Araucanians of that time appear to us as a case of the development of a culture beginning with a national spirit: resistance to domination and self-sufficiency. Moreover, we see that there arose among the Araucanians an increasingly intense and previously unknown national interest. Thus, we have proof of the tenacity of the link, of the nature of cultural traits with the land, of what Kroeber calls, "the capacity of a culture to absorb and resist at the same time." Which, over many years, for all that cultural borrowings diffuse into its interior, succeeds in finding the dynamic principle to organize their society: warfare (Leiva 1977:160).

If creating an ethnic nationalism (sensu Padden and Leiva; Dillehay 2007) and a defense system were the conditions of making the polity, governance was a project of managing and redistributing it across emerging, shifting, networking, and changing kin and non-kin subjects, and religious ceremonial nodes of a developing wider and transformed multi-ethnic membership. This might suggest that Araucanian polity-formation, sovereignty, and selfdetermination were private, religious, and kin-related before they were public, civic, and political. That the Araucanian polity authorities had invested in subjects and kinship is not a new insight. But that polity authorities increasingly implicated themselves in governing mixed kin and non-kin members through a growing number of reconstituted kin and nonkin communities, initially from the lof and regua levels to the ayllaregua and the butanmapu levels, makes governance or governing the social structure a significant object of the political organization of the new polity within an ambiance of conflict and warfare (c.f., Boccara 1999; Zavala 2008). This is a fundamental characteristic of most indigenous polities (Barker 2005; McCue 2007).

As a result of warfare with the Spanish and with shifting alliances and mixed communities, the "sovereign" territorial polity of the Estado had a basic and distinctive interest in controlling the flow of persons within and across its domains, in being able to compel, induce, discourage, or forbid the entry or exit of particular categories of persons-i.e., 
Spanish outsiders and their allied indios amigos, and in recruiting new populations to the war effort. However, what the Araucanians could never achieve in their thrust toward polity formation was complete territorial closure and a formal ethnic political boundary by occupying a centralized controlling position in the web of interregional interaction. Even within the Estado, complete administrative closure was never achieved. A neutral or uncommitted community and an ever-changing and allied indio amigo population prevented centralization and ethnic closure. Leaders of the polity never succeeded in excluding these groups from their territory (see Dillehay and Zavala 2013; Zavala 2008, 2011), which may suggest that the idea and practice of this indigenous sovereignty was a fleeting condition.

In summary, the political structure of the polity blended the primordial understanding of territorial defense with an increasing perspective toward management of larger, more composite patrilineal units made of both fictive and non-fictive kin, and it marked the transition necessary to a more complex style of political leadership, one not just given to security and protection but to cultural survivability, ethnic polity formation, continued self-rule, and economic sustainability. This complex of Araucanian people and things constituted the social power "located not in bounded, singular, or a sovereign state, but in customs, rules, processes, and multi-level institutions" (see Prodi 2000). In the end, social and kin membership was above all about redistributive politics across a largely mixed population and about a fleeting but still effective sovereignty and sense of self-determination.

\section{Ethnic Identity and Sovereignty}

In the Estado, the "conceived order" or "imagined community" and the institutional realities of ethnicity and nationalism were fused. A sovereign ethnic field was a cultural fact to the Araucanians; to colonial Spain, it was a political curse. To the extent that an indigenous sovereign "identity" makes scholarly sense at all, the subjective identity of the vast majority of the Araucanian population throughout the Arauco War was largely political on the one hand and religious on the other.

In returning to the notion of ontological rupture, the Spanish understandings of sovereignty and statehood were more assimilationist, the Araucanian understanding was more conglomerative and survivalist. The gradual formation of the Spanish empire around a single major political and cultural center in Europe was the historical matrix for an assimilationist self-understanding. On the other hand, the conglomerative pattern of polity-building in the Araucania was the historical matrix for a more differentialist self-determination and self-identity of ethnicity and nationalism.

Ultimately, by the $18^{\text {th }}$ and early $19^{\text {th }}$ centuries, the Araucania region became a landscape broken up by internal contradictions and the absence of strict control by either side, but only during those times when the Spanish had a military presence in Araucanian territory. However, these contradictions ultimately favored the wider political objectives of the Araucanians at the expense of the Crown. The Spanish, who overtly prioritized disunity among the different indigenous population segments, never understood that the Araucanians could assemble a strategic political unity out of a functional disunity and decentralization, which partly accounts for the prolonged success of the latter in their campaigns against the former. This strategic unity was brought about by the presence of the larger proportion of indios enemigos and their ability to convert many indios amigos of the Spanish to their side. The end result was an unreliable group of allied indios fighting alongside the Spanish. As insinuated by Padden, disunity and ambivalence guaranteed Araucanian self-determination and self-rule and their destiny.

Self-rule and self-defined destiny are important issues for most indigenous peoples since one of the most long-standing impositions that these people have endured from modern-day governments and others is external control, management and direction (c.f., Corntassel and Primeau 2011; Graham and Wiessner 2011; Perry 2011). From the earliest days of the loss of or relocation from traditional lands for many populations, through 'protective' isolation and then assimilation policies, the Araucanians or Mapuche have been denied their right to be self-determining within Chile and Argentina's the economic, social, political and legal structures of Chile and Argentina. Since the terminal $19^{\text {th }}$ century, these peoples were also given little or no opportunity to contribute to the content of the foundation governing structures of these nations. Nonetheless, they continue to claim sovereignty over their lands. The 150th anniversary commemoration of the indigenous "Mapuche Kingdom of Araucania and Patagonia" was celebrated on November 17, 2010, a historic 
landmark celebration which paradoxially took place during the bicentenary of the modern republics of Chile and Argentina. Recently, upon the 2014 election of President Michelle Bachelet, Mapuche leaders once again called for a sovereign indigenous nation within the Chilean state.

\section{The Mapuche in Present-Day Chile}

The national constitution of Chile legally and historically accepts the presence of one population, the Chileans (El Diario Oficial 2002). Until the passage of the National Indigenous Law (1993), the Chilean government had primarily ignored the existence of indigenous peoples, except when dealing with their lands and the means to incorporate them into the individual property system. This denial extended to the Chilean identity, since literature and popular culture promoted the idea of the Chilean people as "the English of South America." Chilean cultural perception of indigenous peoples is largely locked in the mythological past. The historical image of the indomitable Mapuche resisting the Spanish intrusion into their lands remains socially accepted and sometimes promoted (e.g., Millaleo 2011).

Land, in the Mapuche struggle, is a transcendent concept. It is not simply a plot of terra firme demarcated by a vague set of boundaries, as it is in the liberal Enlightenment thinking that constitutes Western thinking. Land is a living, inalienable thing that serves as the basis for a community's existence. Accordingly, the Mapuche's struggle for the land is not a campaign to gain property titles so they can farm it, sell it, or build on it, however they please. It is a conflict between two different worldviews, today that of the Mapuche and Chileans. It is a prolonged effort to restore the Mapuche's traditional relationship with the land in opposition to that of Western society, which, in the name of liberty makes "free life impossible" (A. Huenchulaf, pers. comm., 2013; c.f. Bengoa 2013; Millaleo 2011; Richards 2013).

Within the current Mapuche struggle for sovereignty, there is no apparent alienation between means and ends, and no separation between political, religious, economic, and cultural solutions. As some Mapuche communities occasionally receive back some lands, the lands are ideally removed from the logic of commercial production and reconnected to a web of living beings. Often, this means planting quinoa, corn, potatoes and other traditional crops or grazing livestock, as the Mapuche have for several centuries, so the communities can feed themselves without reliance on a market economy for which they have been expendable for the past 120 years or so. Another desired transformation is the removal of commercial timber plantations and reintroduction of native tree species. This would help the local environment to heal, and also brings back the plants the Mapuche use for their medicine and ceremonies.

For those scattered Mapuche communities currently in resistance, bettering their circumstances usually means implementing their own solutions at a local level, it ideally means being able to feed themselves directly, independent of the price of bread or whatever cash crop they are supposed to grow, it means healthy land, clean air and water, traditional medicine and nature-based religion. It also means an autonomous Mapuche territory or "Mapuche Nation" (Figure 1).

Until recently, there was little awareness among non-indigenous Chileans of the idea of a contemporary "Mapuche Nation" and the Mapuche's aspirations and struggles. This situation changed slightly in 2012, when the official population census showed that almost one million Chileans, of a total of nearly twenty million, declared themselves to be Mapuche, the largest ethnic group in Chile (Instituto Nacional de Estadísticas 2010). According to the census, about twenty percent of Mapuche live in the Araucania, the heartland of Mapuche traditional territory, where they make up $29 \%$ of the total regional population, the highest concentration in Chile. Forty-four percent of Mapuche live in the Santiago, where they make up approximately $10 \%$ of the population. The recent census testifies to the survival of the Mapuche while documenting their significant presence in Chile.

Large majorities of the Mapuche, however, do not strive for self-rule and an independent nation, but there is a growing resisting population in both the urban and rural sectors of the country. There also is increased conflict between the Mapuche and the Chilean government. For many Mapuche, the solution to overcoming this conflict is Mapuche "self-determination" and an end to "the occupation of the Mapuche territory by Chile" (political discourse of several Mapuche leaders with candidates for the office of the presidency of Chile, Temuco, 2013; personal observation). However, despite the fact that the Mapuche are the largest indigenous group in Chile, 


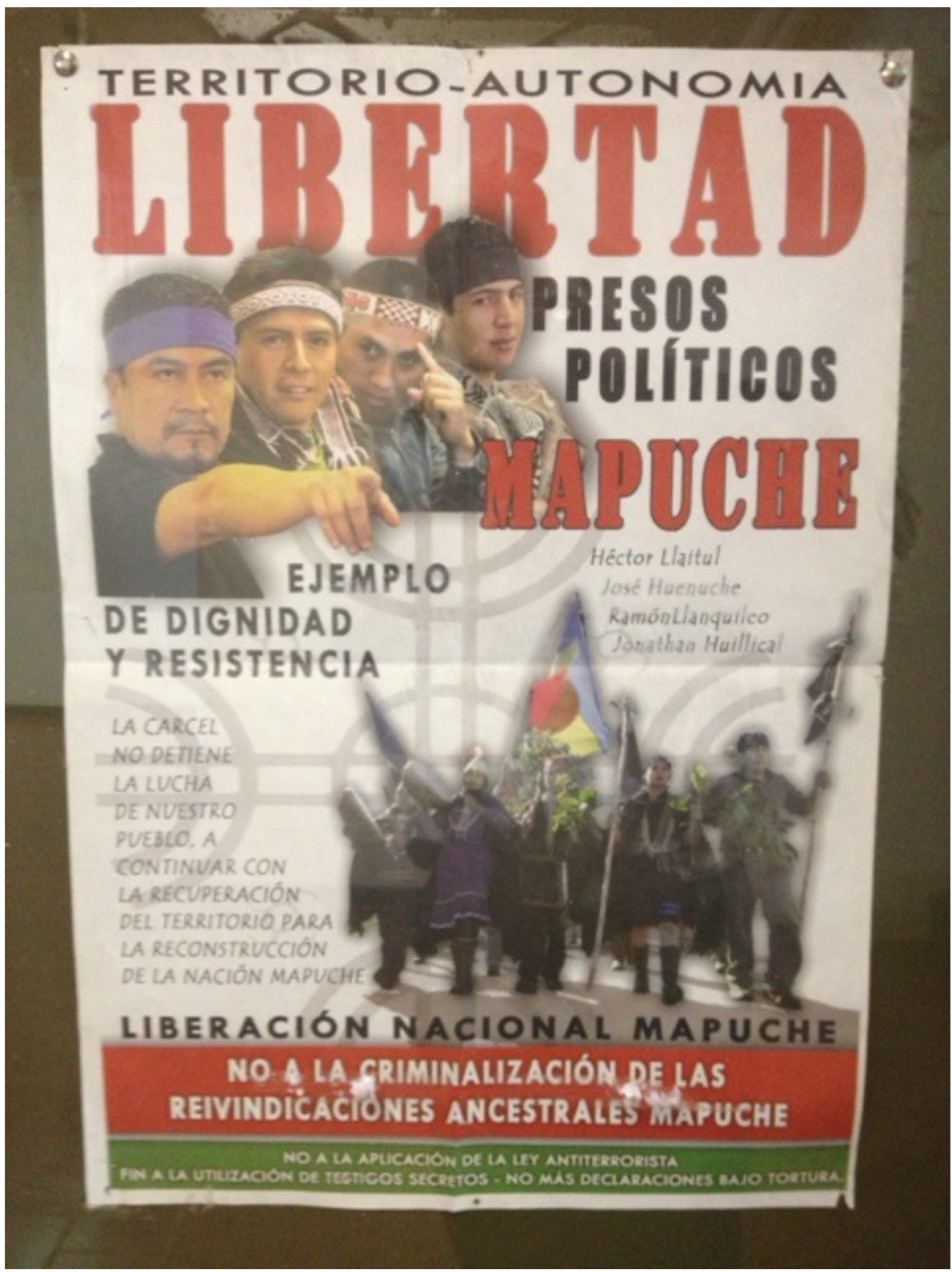

Figure 1. A 2013 political poster calling for the release of jailed Mapuche political leaders and for an autonomous indigenous territory.

constituting approximately $8 \%$ the total population, its political leverage in pursuing self-determination and an independent nation is limited to a single Mapuche congressman. It thus has become important for the Mapuche to develop a strong legal argument that can support their aspirations for land rights and self-determination, an argument that they hope will raise the attention of the Chilean government and the international community. In expressing these aspirations, some Mapuche have proposed several models of independence and self-determination, all of which revolve around the concept of parallel 
sovereignty (see footnote 2). This concept involves two major proposals with several variations: (1) self-governance of the scattered rural and urban indigenous population without a formal state- or nation-territory with formal international borders; and (2) a portion of the Araucania region, preferable where the Estado once was, to be recognized as a new indigenous nation in Chile (see Marriman 2013). In other words, a nation within a nation-state or parallel sovereignty.

Indigenous sovereignty, just like any claim to sovereignty, is not easily granted anywhere in the world. It inheres in its creator; it develops, or it fades away, from within. The 2007 United Nations Declaration on the Rights of Indigenous Peoples is based on the universal recognition of their claim to self-determination on their lands, an aspiration that lies at the center of the rising Mapuche's peoples' claims to re-empowerment. In important respects, particularly regarding their rights to their territories, their culture, and internal self-government, the Declaration reaffirms pre-existing rules of customary international law and treaty law. The right to recapture their historical identity, to reinvigorate their ways of life, to reconnect with and regain their traditional lands, to protect their heritage, to revitalize their languages and manifest their culture-all of these rights are as important to indigenous people as the right to make decisions in their internal political, judicial, and economic settings. International and domestic law can support and protect these rights and decisions.

\section{References Cited}

Aylwin, J. 1998. Indigenous Rights in Chile: Progresses and Contradictions in a Context of Economic Globalization Presented at the Canadian Association for Latin American and Caribbean Studies (CALACS) XXVIII Congress. Simon Fraser University Press, Vancouver.

Barker, J. 2005. For whom sovereignty matters. In Sovereignty Matters: Locations of Contestation and Possibility in Indigenous Struggles for Self-determination, edited by J. Barker, pp. 1-32. University of Nebraska Press, Lincoln.

Bateman, C.G. 2011. Nicaea and Sovereignty: Constantine's Council of Nicaea as an Important Crossroad in the Development of European State Sovereignty. University of British Columbia Press, Vancouver.

Bengoa, J. 1999. Historia de un Conflicto: El Estado y los Mapuches en el Siglo XX. Planeta, Santiago.

Bengoa, J. 2003. Historia de los Antiguos Mapuches del Sur. Catalonia, Santiago.

Bengoa, J. 2013. Mapuche: Procesos, Políticas y Culturas en el Chile del Bicentenario. Catalonia, Santiago.

Boccara, G. 1998. Guerre et Ethnogenèse Mapuche dans le Chili Colonial: L'Invention du Soi. L'Harmattan, Paris.

Boccara, G. 1999. Etnogénesis mapuche: resistencia y restructuración entre los indígenas del centro-sur de Chile (siglos XVI-XVIII). Hispanic American Historical Review 79:425-461.

Boccara, G. 2002. Colonización, resistencia, y etnogénesis en las fronteras Americanas. In Colonización, Resistencia, y Mestizaje en las Américas, Siglos XVI-XX, edited by G. Boccara, pp. 47-82. Ediciones Abya-Yala, Quito.

Boccara, G. and P. Bolados 2008. Etnogénesis mapuche: resistencia y restructuración entre los indígenas del centro-sur de Chile (siglos XVI-XVIII). Memoria Americana 16:167-196.

Brysk, A. 2000. From Tribal Village to Global Village: Indian Rights and International Relations in Latin America. Stanford University Press, Palo Alto.
Corntassel, J. and T. Primeau 2011. Indigenous sovereignty and international law: Revised strategies for pursuing "self-determination." Human Rights Quarterly 17:343-365. HeinOnline.

Comisión de Comunicaciones 2013. La situación del pueblo Mapuche y su lucha por la libre determinación. http://meli. mapuches.org/spip.php?rubrique16. (accessed January 23, 2015)

Crow, J. 2013. The Mapuche in Modern Chile: A Cultural History. University Press of Florida, Gainesville.

Dean, B.C. and J.M. Levi (eds.) 2003. At the Risk of Being Heard: Identity, Indigenous Rights, and Postcolonial States. The University of Michigan Press, Ann Arbor.

Dillehay, T.D. 2007. Monuments, Resistance and Empires in the Andes: Araucanian Ritual Narratives and Polity. Cambridge University Press, Cambridge.

Dillehay, T.D. 2014. The Teleoscopic Polity: Andean Patriarchy and Materiality. Springer Verlag Press, Berlin.

Dillehay, T.D. and J. Zavala 2013. Compromised landscapes: The proto-panoptic politics of colonial Araucanian and Spanish parlamentos. Colonial Latin American Review 22:320-342.

El Diario Oficial 2002. Santiago, Chile.

Ercilla y Zúñiga, A. De 1982 [1569]. La Araucana. Editorial Universitaria, Santiago.

Faron, L.C. 1962. Symbolic values and the integration of society among the Mapuche of Chile. American Anthropologist 64:1151-1164.

Fowler, M.R. and J.M. Bunck. 1995. Law, Power, and the Sovereign State: The Evolution and Application of the Concept of Sovereignty. Penn State University Press, University Park, PA.

Goicovich, F. 2003. En torno a la asimetría de los géneros en la sociedad Mapuche del período de la conquista Hispana. Historia 36:159-178. 
Goicovich, F. 2006. Alianzas geoétnicas en las segunda rebelión general: génesis y dinámica de los vutanmapus en el alzamiento de 1598. Historia 39:93-154.

Gongora Marmolejo, A. de 1990 [1575]. Historia de Todas las Cosas que han Acaecido en el Reino de Chile y de los que lo han Gobernado (1536-1575). Ediciones de la Universidad de Chile, Santiago.

Gonzalez de Najera, A. 1889 [1614]. Desengaño y Reparo de la Guerra de Chile. Imprenta Ercilla, Santiago.

Graham, L.M. and S. Wiessner 2011. Indigenous sovereignty, culture, and international human rights law. South Atlantic Quarterly 110:403-427

Haughney, D. 2006. Neoliberal Economics, Democratic Transition, and Mapuche Demands for Rights in Chile. The University Press of Florida, Gainesville.

Herr, P.M. 2014. The nation-state according to whom? Mapuches and the Chilean State in the early nineteenth century. Journal of Early American 4:66-94.

Hunefeldt, C. and L. Sussex (eds.) 2011. Ethnicity from Various Angles and Through Varied Lenses: Yesterday's Today in Latin America. Academic Press, New York.

INE 2010. Instituto Nacional de Estatistica. Santiago, Chile. http://www.ine.pt/xportal/xmain?xpid=INE\&xpgid=ine_main, (1 Dec. 2013).

Krasner, S.D. 1999. Sovereignty: Organized Hypocrisy. Princeton University Press, Princeton.

Figueroa Cornejo, A. 2015. Nación Mapuche. Héctor Llaitul: La política actual del Estado capitalista favorece al fascismo en el sur de Chile. resumenlatinoamericano.org/2015/08/31/ nacion-mapuche-hector-llaitul-la-politica-actual-del-estadocapitalista-favorece-al-fascismo-en-el-sur-de-chilel (accessed June 19, 2014)

Leiva, A. 1977. Rechazo y Absorción de Elementos de la Cultura Española por los Araucanos en el Primer Siglo de la Conquista de Chile (1541-1655). Tesis de Licenciatura, Facultad de Ciencias Humanas, Universidad de Chile, Santiago.

Lenzerini, F. 2006. Sovereignty revisited: International law and parallel sovereignty of indigenous peoples. International Law Journal 42:155-189.

Mariño de Lobera, P. 1960. Crónica del Reino de Chile. Editorial Atlas, Madrid.

Marriman, J.A. 2013. Autodeterminacón: Ideas Políticas Mapuche en el Albor del Sigle XXI. LOM, Santiago.

McCue, J. 2007. New modalities of sovereignty: An indigenous perspective, 2. Intercultural Humanities Literature Review 19:24-25.

Medina, A. 1978. El Estado Araucano. Boletín de Prehistoria 7-8:23-50.

National Indigenous Law 1993. Congreso de Chile, Valparaiso, Chile.

Millaleo, S. 2011. La recreación de la identidad étnica en la protesta Mapuche: Un punto de partida para el uso de la teoría de sistemas sociales en la política de la identidad. Revista de Antropología 23:51-79.
Olaverría, M. de 1852 [1594]. Informe de Don Miguel de Olaverría sobre el Reyno de Chile, sus Indios y sus guerras. In Historia Física y Política de Chile, Documentos (vol. 2), pp. 13-54. Casa del Autor, Paris.

Padden, R. 1993. Cultural adaptation and militant autonomy among the Araucanians of Chile. In The Indian in Latin American History, edited by J. Kicza, pp. 69-88. Scholarly Resources, Delaware.

Pavlik, S. 2008. In Honor of Vine Deloria, Jr. (1913-2005). http:// www.nwic.edu/deloria/memoriam.pdf, (accessed May 12, 2013)

Perry, R. 2011. Balancing rights or building rights - reconciling the right to use customary systems of law with competing human rights in pursuit of indigenous sovereignty. Journal of Harvard Human Rights 24:71-114.

Prodi, R. 2000. 'Shaping the New Europe', Speech delivered to the European Parliament in Strasbourg, 15 February 2000. http://europa.eu.int/rapid/pressReleasesAction.do? reference $=$ $S P E E C H / 00 / 41 \&$ format $=H T M L \&$ aged $=1 \&$ language $=E N \& g$ uiLanguage $=$ en $($ accessed December 4, 2013)

Richards, P. 2013. Race and the Chilean Miracle: Neoliberalism, Democracy and Indigenous Rights. Pitt Latin American Series, Pittsburgh.

Rosales, D. De 1989 [1674]. Historia General del Reino de Chile (vol. 1). Editorial Andrés Bello, Santiago.

Sahlins, M. 1985. Islands of History. The University of Chicago Press, Chicago.

Sauer, J.J. 2012. Long-Term Resilience In Cultural Systems: An Araucanian Example From Santa Sylvia, South-Central Chile. PhD Dissertation, Department of Anthropology, Vanderbilt University, Nashville.

Shore, C. 2000. Building Europe: The Cultural Politics of European Integration. Routledge, London.

Taiaiake, A. 2005. Sovereignty. In Sovereignty Matters: Locations of Contestation and Possibility in Indigenous Struggles for Self-determination, edited by J. Barker, 33-50. University of Nebraska Press, Lincoln.

Taylor, C. 2004. Modern Social Imaginaries. Duke University Press, Durham.

U.N. Economic and Social Council [ECOSOC], U.N. 1996. Committee on Human Rights, Sub-Comm'n on Prevention of Discrimination \& Prot. of Minorities, Working Group on Indigenous Populations. Report of the Working Group on Indigenous Populations on its Eleventh Session, U.N. Doc. E/ CN.4/Sub.2/1993/29 (1993).

Valdivia, L. de 1887 [1606]. Arte, Vocabulario y Confesionario en la Lengua de Chile. B.G. Teubner, Leipzig.

Wallace, W. 1996. Government without statehood: the unstable equilibrium. In Policy-Making in the European Union, edited by H. Wallace and W. Wallace, pp. 430-460. Oxford University Press, New York.

Weber, C. and T.J. Biersteker 1996. Reconstructing the analysis of sovereignty: concluding reflections and directions for future research. In State Sovereignty as Social Construct, edited by C. Weber and T.J. Biersteker, pp. 278-286. Cambridge University Press, Cambridge. 
Zavala, J.M. 2000. Les Indiens Mapuche du Chili. L'Harmattan, Paris

Zavala, J.M. 2008. Los Mapuches del Siglo XVIII. Dinámica Interétnica y Estrategias de Resistencia. Editorial Universidad Boliviarana S.A., Santiago.
Zavala, J.M. 2011. Origen y particularidades de los parlamentos hispano-mapuches coloniales: entre la tradición europea de tratados y las formas de negociación indígenas. In Pueblos Indígenas y Extranjeros en la Monarquía Hispánica: la Imagen del Otro en Tiempos de Guerra, siglos XVI-XIX, edited by D. González Cruz, pp. 83-97. Silex Ediciones, Madrid.

\section{Notes}

1 Legal recognition of indigenous sovereignty came from delegitimization of the conceptual grounding of "Conquest" in the concept of terra nullius, which European powers had used to justify the acquisition of overseas lands by conquest-not only disregarding the will of the conquered original inhabitants of the land, but treating them as legally irrelevant-as Aristotelian "natural slaves," as in the Spanish version of the Conquest. Today, the international community believes that the use of this concept in the acquisition of inhabited land is racist, as stated in the 2007 UN Declaration on the Rights of Indigenous Peoples. This Declaration sets forth the right of indigenous groups to participate, "if they so choose," in the political, economic, social, and cultural life of the nation state: "First, indigenous peoples are entitled to maintain and develop their distinct cultural identity, their spirituality, their language, and their traditional ways of life. Second, they hold the right to political, economic and social self-determination, including a wide range of autonomy and the maintenance and strengthening of their own system of justice. Third, indigenous peoples have a right to demarcation, ownership, development, control and use of the lands they have traditionally owned or otherwise occupied and used. Fourth, governments are to honor and faithfully observe their treaty commitments to indigenous nations."

2 There also is the concept of "parallel sovereignty," which is the recognition of "indigenous nation" sovereignty within a sovereign nation state (Lenzerini 2006). 